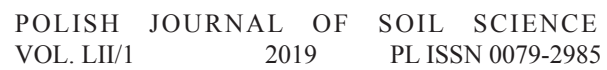

DOI: $10.17951 / \mathrm{pjss} / 2019.52 .1 .43$

OMID BAHMANI*

\title{
EVALUATION OF THE SHORT-TERM EFFECT OF TILLAGE PRACTICES ON SOIL HYDRO-PHYSICAL PROPERTIES
}

Received:05.05.2018

Accepted:19.02.2019

\begin{abstract}
Tillage is one of the most important practices that have a significant influence on the soil hydro-physical properties. In this study, the impact of the type and number of input variables with five different methods of the Retention Curve program (RETC) to predicting the moisture retention curve and soil water content in three tillage surfaces - NT (no-tillage), CP (chisel plough) and MP (moldboard plough) - and the impact of tillage systems on soil hydro-physical properties were evaluated. According to results, when the field capacity and wilting point were added to input data in RETC to predict the moisture curve model parameters, the EF was increased in MP $(0.977,0.95)$ and $\mathrm{CP}(0.891,0.86)$ treatments when compared to NT $(0.665,0.608)$. The MualemVan Genuchten model can satisfactorily describe the simulation of soil physical properties. The S-index, which was also affected by tillage, was greater than 0.066 in all tillage treatments, indicating good soil physical quality. Results indicated that NT had the highest and lowest values of bulk density $\left(1.55 \mathrm{mg} \cdot \mathrm{m}^{-3}\right)$ and total available water (TAW) $\left(0.038 \mathrm{~m} \cdot \mathrm{m}^{-1}\right)$, respectively, and the difference between NT and MP in total porosity was significant. Overall, in most soil layers, tillage practices affected the porosity and TAW in the order MP $>\mathrm{CP}>$ NT. Water retention curves indicated that the water retention capacity was greater in tilled than in no-tilled surfaces, and saturated hydraulic conductivity values were greater in tilled treatments than in NT one.
\end{abstract}

Keywords: tillage, soil hydraulic properties, soil water retention

* Department of Water Engineering, Faculty of Agriculture, Bu-Ali Sina University, Hamedan, Iran. Author's e-mail: omid.bahmani@basu.ac.ir 


\section{INTRODUCTION}

Understanding of important processes in agriculture and the environment needs to have adequate information on soil physics. One of the most important characteristics that describe the unsaturated soil is the soil water characteristic curve, which in many studies is used as basic information. The soil water characteristic curve is a fundamental soil property employed to quantify plant available water and for modeling water and solute movement in soils.

Unfortunately, laboratory and field methods, which developed over the years to measure the hydraulic functions are relatively costly, difficult to implement and time-consuming (Van Genuchten et al. 1991).

The structure, porosity, pore size distribution of soil and other characteristics of water retention in the soil and water conservation show how different matric for each soil is unique. Matric potential and moisture content changes have a complex relationship with nonlinear function (Van Genuchten 1980, Walczak et al. 2006).

The total available water content (TAW) is used with regard to crop water requirement, regional or global change, soil-vegetation-atmosphere relation studies, or for agricultural purposes. The TAW content is defined as the difference between FC and WP (Givi et al. 2004). Soil water characteristic curve (SWCC) can be explained as a measure of the water retention capacity of the soil as the water content changes when subjected to different values of suction (Adefemi and Wole 2013).

Many mathematical models were proposed to measure the soil moisture curve (Tyler and Wheatcraft 1992). Generally, the model curve is more successful since one can estimate the sigmoid shape of moisture; we can point out the Van Genuchten model (1980). Retention Curve program (RETC) is a computer program used for analyzing soil water retention and hydraulic conductivity functions of unsaturated soils (Van Genuchten et al. 1991). The RETC program utilizes the least squares optimization approach to estimate the hydraulic conductivity and unknown model parameters from observed retention data. Soil structure and moisture removal changes are dependent on soil properties, types of tillage and climatic conditions. Dexter (2004) proposed the S-index (Si), an indicator of soil physical and structural quality, which has been related to many important soil properties or conditions, including hydraulic conductivity, compaction, tillage, penetration resistance, plant-available soil water, root growth, and soil structural stability. The Dexter S-index is a promising new indicator of soil physical quality. The S-index derived from the slope of the soil water retention curve at its inflection point is used by a number of authors (Gate et al. 2006, Dexter and Richard 2009). Air capacity, plant-available water capacity, relative field capacity and S-index depend directly on soil porosity and soil water release characteristics. Data from various experiments depicting various agricultural management (tillage, fertilizer 
and organic manure) practices were analyzed to retrieve Si from the soil physical parameters mostly affected by the treatments. Dexter (2004) expressed that Si can be used as a soil physical quality index to compare different soil physical conditions and different soils or the effect of management practices.

Hydro-physical soil properties (bulk density, macro and micro porosity, pore size distribution, water storage, infiltration rate and hydraulic conductivity) change with the variation in the soil structure (Gill 2012). Tillage implements can change the soil structure because of the mechanical effect (Alletto and Coquet 2009).

The degree of soil loosening and overturn by tillage depends on soil texture, soil moisture, organic matter and type of tillage operation. The relationship between soil properties and tillage has not been completely defined. Tillage practices induce changes in soil physical properties such as soil bulk density, macro and micro pores, hydraulic conductivity and water storage in soil (Jabro et al. 2015). Another study showed that the different tillage treatments affected on soil physical properties, but the changes were not significant (Kovac and Zak 1999). Nkakini and Fubara-Manuel (2012) reported that different tillage systems (plowing, plowing + harrowing, plowing + harrowing + harrowing, and ridging) had no significant effect on the total porosity of soil and penetration resistance.

The objectives of this study were to evaluate the influence of three different tillage practices - MP (moldboard plow), CP (chisel plow), and NT (no-tillage) - on bulk density, total porosity, micro and macro porosity, total available water, hydraulic conductivity and the shape of the water retention curve of a sandy loamy soil in a semi-arid region of Iran and Van Genuchten model was fitted to the experimental data from three tillage systems using the RETC.

\section{MATERIALS AND METHODS}

The experimental field was located in the Research Station of the Faculty of Agriculture in Bu-Ali Sina University of Hamedan, Iran (34 $\left.52^{\prime} \mathrm{N}, 48^{\circ} 32^{\prime} \mathrm{E}\right)$. Three tillage surfaces consisting of: no-tillage (NT), reduced tillage with the chisel plow (CP) and conventional tillage with the moldboard plow (MP) at depths of $0-15$ and $0-22.5 \mathrm{~cm}$, respectively, were considered. The experiment was planned according to a randomized complete block design with three replicates, and nine plots for three different tillage practices were arranged in the experimental field. Each plot area was $12 \mathrm{~m}$ wide and $40 \mathrm{~m}$ long. Samples were taken from three depths of 0-7.5, 7.5-15 and $15-22.5 \mathrm{~cm}$ in all treatments after a year of corn cultivation. Soil physical properties were determined as follows: soil texture analysis was carried out by the hydrometer method of Gee and Bauder (1986); the particle size distribution was further classified as sand, silt, 
clay according to USDA. Undisturbed soil samples were collected for determining soil bulk density using a cylindrical soil sampler $5 \mathrm{~cm}$ long and $5 \mathrm{~cm}$ in diameter. Total porosity was calculated from bulk density and particle density (particle density is approximately $2.65 \mathrm{mg} \cdot \mathrm{m}^{-3}$ for mineral soils with low organic matter), air capacity was calculated as a difference between total porosity and water holding capacity. Saturated hydraulic conductivity (Ks) was also measured in the laboratory by the constant head method (ASTM D5084-03). Duncan's multiple range tests were used for the statistical analysis. The data were analyzed using standard error and the differences were accepted as significant if $\mathrm{p}<0.05$. Before the experiment, some properties of the studied soil were determined according to the standard methods and are given in Table 1.

Table 1. Properties of the studied soil sample

\begin{tabular}{cccccccc}
\hline $\begin{array}{c}\text { Depth } \\
(\mathrm{cm})\end{array}$ & $\begin{array}{c}\text { Sand } \\
(\%)\end{array}$ & $\begin{array}{c}\text { Silt } \\
(\%)\end{array}$ & $\begin{array}{c}\text { Clay } \\
(\%)\end{array}$ & Texture class & Bulk density $\left(\mathrm{g} \cdot \mathrm{cm}^{3}\right)$ & $\begin{array}{c}\text { OM } \\
(\%)\end{array}$ & $\begin{array}{c}\text { EC } \\
(\mathrm{ds} \cdot \mathrm{m})\end{array}$ \\
\hline $0-22.5$ & 62.2 & 26 & 11.8 & Sandy loam & 1.48 & 0.34 & 0.33 \\
\hline
\end{tabular}

In order to estimate the moisture retention curve of Mualem-Van Genuchten there was used the RETC model, and the type and number of input variables in this model were assessed. The RETC model allows the estimation of water retention and the saturated hydraulic conductivity using limited to more extended input data. Soil moisture characteristic curve and hydraulic functions and their variables can be determined using the number of points as suction and the moisture with the neural network method in the form of five different methods by RETC. The samples' SWRC was constructed by measuring soil water content at 12 soil-matric potentials using the undisturbed soil samples. Data and soil retention curve (volumetric soil moisture values in 12 different suction: $0,-1,-2,-5,-10,-20,-50$, $-100,-200,-500,-1,000,-1,500 \mathrm{kPa}$ ) corresponds to a sandy loam soil from 0 to $30 \mathrm{~cm}$ depth were used. For the pressure potentials ranging from -1 to $-10 \mathrm{kPa}$, the sand box apparatus was used. The undisturbed subsamples were used to determine water content at -1 to $-50 \mathrm{kPa}$ and the disturbed subsamples for water content determination at -100 to $-1,500 \mathrm{kPa}$ using a pressure plate (Lin and Cerato 2012).

In this study, five different levels of inputs to the pedotransfer functions in the RETC were considered. These inputs consist of TC (soil texture), SSC (sand, silt and clay), SSCBD (sand, silt, clay and bulk density), SSCBDӨ33 (sand, silt, clay, bulk density, moisture content at $-33 \mathrm{kPa}$ ) and SSCBDӨ33\&1,500 (including the amount of sand, silt, clay, bulk density, moisture content at -33 and $-1,500 \mathrm{kPa}$ ). The five models were evaluated to estimate accurately the moisture retention curve in the three levels of tillage (NT, CP and MP).

Soil water retention curve (SWRC) data were adjusted using the Van Genuchten equation (eq. 1) with the Mualem restriction $(\mathrm{m}=1-1 / \mathrm{n})$ (Van Genuchten 1980, Mualem 1976): 


$$
\theta=\frac{\theta_{s-} \theta_{\mathrm{r}}}{\left[1+(\alpha \mathrm{h})^{\mathrm{n}}\right]^{\mathrm{m}}}+\theta_{\mathrm{r}}
$$

Where: $\theta_{S}$ and $\theta_{r}$ represent the saturated and residual water contents, respectively; $\alpha$ is the scaling factor for $h$; and $m$ and $n$ parameters are related to the shape of the fitted curve. The Van Genuchten et al. (1991) RETC (Retention Curve program) was used to fit mean $\theta$ and $h$ data for each soil and treatment. Equation (1) was fitted to the measured data of each soil sample using a nonlinear least-squares optimization approach that minimized the sum of squared deviations (SSQ) between observed and fitted water contents.

The slope of the $\theta(h)$ vs. $\ln (h)$ function, $S(h)(-)$, is given by:

$$
\mathrm{S}(\mathrm{h})=\frac{\mathrm{d}(\theta)}{\mathrm{d}(\operatorname{lnh})}=-\mathrm{mn}\left(\theta_{\mathrm{s}}-\theta_{\mathrm{r}}\right) \alpha^{\mathrm{n}} \mathrm{h}^{\mathrm{n}}\left[1+(\alpha \mathrm{h})^{\mathrm{n}}\right]^{-(\mathrm{m}+1)}
$$

And the magnitude of the slope at the inflection point, $\mathrm{Si}$ is:

$$
\mathrm{S}_{\mathrm{i}}(\mathrm{h})=\frac{\mathrm{d}\left(\theta_{\mathrm{i}}\right)}{\mathrm{d}\left(\operatorname{lnh}_{\mathrm{i}}\right)}=\left|-\mathrm{n}\left(\theta_{\mathrm{s}}-\theta_{\mathrm{r}}\right)\left[1+\frac{1}{\mathrm{~m}}\right]^{-(\mathrm{m}+1)}\right|
$$

Where:

$$
\begin{aligned}
& \theta_{\mathrm{i}}=\left(\theta_{\mathrm{s}}-\theta_{\mathrm{r}}\right)\left[1+\frac{1}{\mathrm{~m}}\right]^{-\mathrm{m}}+\theta_{\mathrm{r}} \\
& \mathrm{h}_{\mathrm{i}}=\frac{1}{\alpha}\left(\frac{1}{\mathrm{~m}}\right)^{\frac{1}{\mathrm{n}}}
\end{aligned}
$$

Where:

$\theta_{i}$ and $h_{i}$ are the water content and tension head at the inflection point, respectively. Details on the derivation of equations (2) and (3)-(5) are given in Dexter (2004).

The S-index has the variation range to obtain the soil physical quality, if $0.035 \leq \mathrm{Si}<0.050$, it is of good physical quality, if $0.020 \leq \mathrm{Si}<0.035$, it is of poor physical quality, and if $\mathrm{Si}<0.020$, it is of very poor or degraded physical quality (Dexter and Czyż 2007, Tormena et al. 2008). The theoretical limits of $\mathrm{Si}$ are $0 \leq \mathrm{Si}<\infty$, however, agricultural soils are within the range of $0.007 \leq \mathrm{Si}$ $<0.14$ (Dexter and Czyż 2007).

\section{Evaluation criteria}

Prediction performances of methods were evaluated by RMSE, ME and EF between the predicted soil water and the determined values and expressed as (Krause et al. 2005): 


$$
\begin{aligned}
& \mathrm{AE}=\frac{\sum_{i=1}^{n}\left(P_{i}-O_{i}\right)}{n} \\
& \mathrm{RMSE}=\left[\frac{\sum_{i=1}^{n}\left(o_{i}-P_{i}\right)^{2}}{n}\right]^{0.5} \\
& \mathrm{EF}=\left(\sum_{\mathrm{i}=1}^{\mathrm{n}}\left(\mathrm{O}_{\mathrm{i}}-\overline{0}\right)^{2}-\sum_{\mathrm{i}=1}^{\mathrm{n}}\left(\mathrm{P}_{\mathrm{i}}-\mathrm{O}_{\mathrm{i}}\right)^{2}\right) / \sum_{\mathrm{i}=1}^{\mathrm{n}}\left(\mathrm{O}_{\mathrm{i}}-\overline{0}\right)^{2}
\end{aligned}
$$

Where: $n$ is the number of moisture curve points, $O_{i}$ is the measured moisture content, $P_{i}$ is the estimated moisture, and $\bar{O}$ is the average of measured moisture. Smaller (more negative) AIC value indicates the better model. Where: $j$ is the number of observations, $k$ is the number of model inputs.

$$
A I C=j \ln \left[\frac{\sum_{i=1}^{j}\left(o_{i}-P_{i}\right)^{2}}{j}\right]+2 k
$$

\section{RESULTS AND DISCUSSION}

\begin{tabular}{|c|c|c|c|c|c|c|c|}
\hline Tillage & Method & $\alpha$ & $\mathrm{n}$ & $\mathrm{m}$ & $\theta_{r}$ & $\theta_{\mathrm{s}}$ & $\mathrm{Si}$ \\
\hline \multirow{5}{*}{ NT } & $\mathrm{TC}$ & 0.027 & 1.448 & 0.310 & 0.039 & 0.387 & 0.076 \\
\hline & SSC & 0.027 & 1.397 & 0.284 & 0.045 & 0.386 & 0.069 \\
\hline & SSCBD & 0.026 & 1.438 & 0.305 & 0.045 & 0.384 & 0.073 \\
\hline & SSCBDӨ33 & 0.039 & 1.536 & 0.349 & 0.046 & 0.377 & 0.082 \\
\hline & SSCBDӨ33\&1,500 & 0.029 & 1.369 & 0.269 & 0.021 & 0.367 & 0.066 \\
\hline \multirow{5}{*}{$\mathrm{CP}$} & $\mathrm{TC}$ & 0.027 & 1.448 & 0.310 & 0.039 & 0.387 & 0.076 \\
\hline & $\mathrm{SSC}$ & 0.027 & 1.397 & 0.284 & 0.045 & 0.386 & 0.069 \\
\hline & SSCBD & 0.026 & 1.438 & 0.305 & 0.045 & 0.384 & 0.073 \\
\hline & SSCBDӨ33 & 0.026 & 1.410 & 0.291 & 0.045 & 0.382 & 0.069 \\
\hline & SSCBDӨ33\&1,500 & 0.015 & 1.391 & 0.281 & 0.024 & 0.370 & 0.069 \\
\hline \multirow{5}{*}{ MP } & $\mathrm{TC}$ & 0.027 & 1.448 & 0.310 & 0.039 & 0.387 & 0.076 \\
\hline & SSC & 0.027 & 1.397 & 0.284 & 0.045 & 0.386 & 0.069 \\
\hline & SSCBD & 0.026 & 1.438 & 0.305 & 0.045 & 0.384 & 0.073 \\
\hline & SSCBDӨ33 & 0.014 & 1.395 & 0.283 & 0.047 & 0.388 & 0.068 \\
\hline & SSCBDӨ33\&1,500 & 0.007 & 1.473 & 0.321 & 0.030 & 0.376 & 0.079 \\
\hline
\end{tabular}

Moisture curve model parameters of sandy loam soil in five methods and three tillage surfaces are presented in Table 2.

Table 2. Moisture curve model parameters for tillage treatments in five methods

In Table 2, saturation volumetric moisture percent $\left(\theta_{s}\right)$ increased by a reduction in compaction and the residual moisture amount $\left(\theta_{r}\right)$ depended on tillage surfaces and would change over tillage treatments similar to $\theta_{s}$ in SSCBDӨ33 and SSCBDӨ33\&1,500 methods.

The increase of pore volume after tillage, which resulted in an increase in $\theta_{s}$, is in agreement with the similar result was reported by Schwen et al. (2011). 
The amount of $\alpha$ decreased in CP and MP tillage surfaces was compared with NT by SSCBDO33 and SSCBDӨ33\&1,500 methods. Santos et al. (2011) stated that compaction decreased $\alpha$. In three methods of TC, SSC and SSCBD, there were no observed changes in all parameters under different tillage because textural pores are related to the distribution of primary soil particles (sand, silt, and clay) and it was constant for all tillage treatments.

In Table 2, in all tillage levels, Si indicated "very good" structural quality $(0.066 \leq \mathrm{S})$. The essential subject of S theory is that soil physical or structural quality as determined primarily by management "structure" pores, rather than texture-induced "matrix" pores. The pore structures such as three-dimensional networks of micro cracks, fractures and interaggregate spaces (i.e. "secondary structure") were created by tillage and other field managements. Tillage decreased the Si value in CP and MP surfaces as compared to the NT surface (SSCBDO33 method). No-tillage treatment might have contributed to greater macro porosity, enhancing soil structure and consequently improved soil physical quality. In a similar study involving reduced and no-tillage systems, the result obtained was $\mathrm{S}>0.035$ (Calonego and Rosolem 2011).

In order to more accurately assess the performance of each method, the statistical indicators were used, and the results are shown in Table 3 for all three levels of tillage. According to statistical parameters, the SSCBDO33 and SSCBDO33\&1,500 methods correspond best to the measured values in MP (RMSE 0.016 and 0.024 , AIC -88.68 and -77.14). Results indicated that the SSCBDO33 method had the best prediction in all tillage systems (NT: RMSE $=0.046, \mathrm{EF}$ $=0.665, \mathrm{CP}: \mathrm{RMSE}=0.3, \mathrm{EF}=0.89, \mathrm{MP}: \mathrm{RMSE}=0.016$, and $\mathrm{EF}=0.977$ ) (Table 3). There is a little difference between methods (TC, SSC, and SSCBD) and it is shown that the moisture curve parameters can be achieved with an initial estimate of primary soil particles.

Table 3. Statistical evaluation of the Van Genuchten model with different input in tillage treatments

\begin{tabular}{|c|c|c|c|c|c|c|}
\hline Tillage & Method & $\mathrm{AE}$ & RMSE & $\mathrm{R}^{2}$ & $\mathrm{EF}$ & AIC \\
\hline \multirow{5}{*}{ NT } & $\mathrm{TC}$ & 0.039 & 0.060 & 0.966 & 0.423 & -65.627 \\
\hline & $\mathrm{SSC}$ & 0.051 & 0.063 & 0.971 & 0.350 & -60.186 \\
\hline & SSCBD & 0.049 & 0.063 & 0.969 & 0.360 & -58.377 \\
\hline & SSCBDӨ33 & 0.014 & 0.046 & 0.970 & 0.665 & -64.145 \\
\hline & SSCBDӨ33\&1,500 & 0.032 & 0.049 & 0.974 & 0.608 & -60.269 \\
\hline \multirow{5}{*}{$\mathrm{CP}$} & $\mathrm{TC}$ & 0.001 & 0.035 & 0.964 & 0.848 & -78.288 \\
\hline & SSC & 0.012 & 0.031 & 0.971 & 0.883 & -77.432 \\
\hline & SSCBD & 0.005 & 0.032 & 0.966 & 0.873 & -74.460 \\
\hline & SSCBDӨ33 & 0.009 & 0.030 & 0.972 & 0.891 & -74.197 \\
\hline & SSCBDӨ33\&1,500 & 0.016 & 0.034 & 0.968 & 0.860 & -69.217 \\
\hline
\end{tabular}




\begin{tabular}{clccccc}
\hline Tillage & \multicolumn{1}{c}{ Method } & AE & RMSE & $\mathrm{R}^{2}$ & EF & AIC \\
\hline \multirow{6}{*}{ MP } & TC & -0.041 & 0.048 & 0.964 & 0.805 & -70.884 \\
& SSC & -0.030 & 0.036 & 0.973 & 0.892 & -73.951 \\
& SSCBD & -0.037 & 0.043 & 0.967 & 0.845 & -67.588 \\
& SSCBDӨ33 & -0.005 & 0.016 & 0.982 & 0.977 & -88.675 \\
& SSCBDӨ33\&1,500 & -0.008 & 0.024 & 0.972 & 0.950 & -77.235 \\
\hline
\end{tabular}

Schaap et al. (2001) showed that the addition of bulk density as input variables decreased a little amount of root mean square error (RMSE) in estimated parameters in the Van Genuchten model.
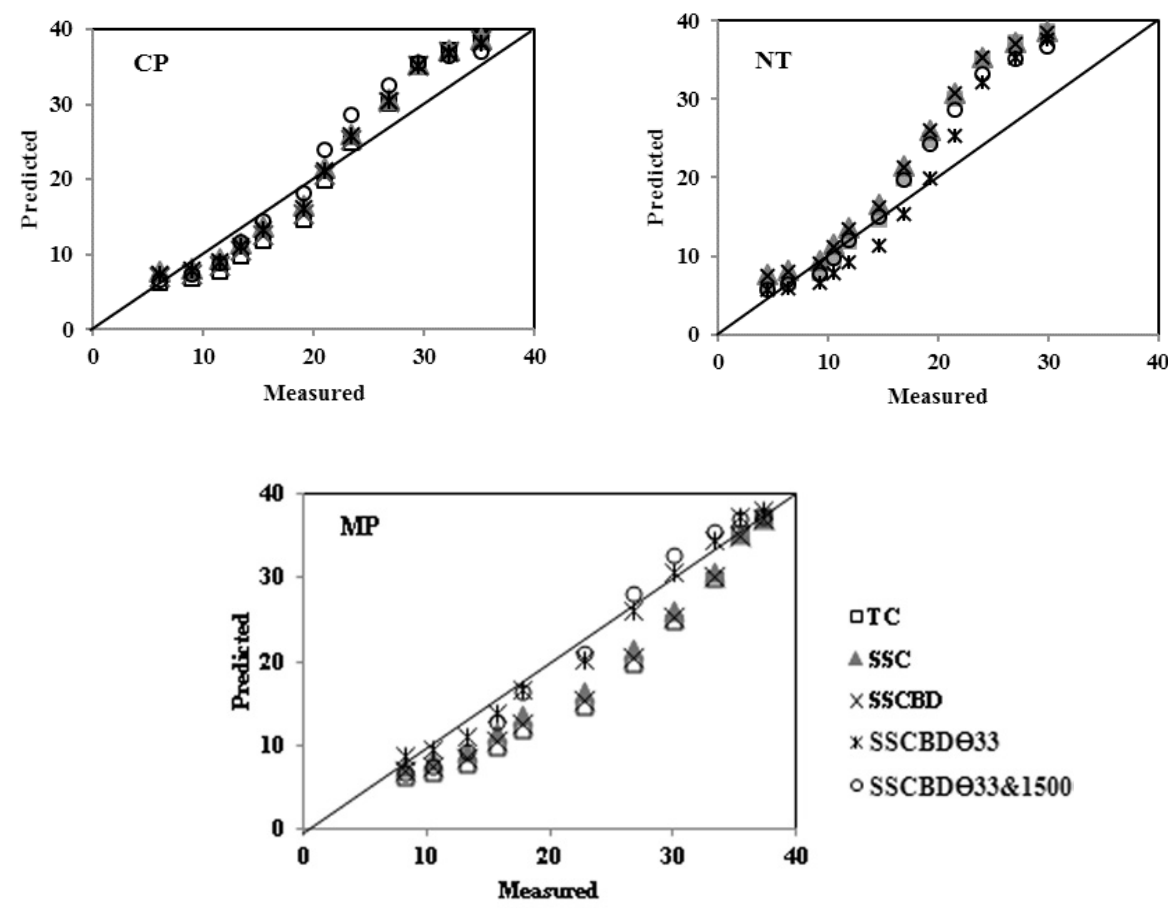

वTC

$\triangle S S C$

$\times$ SSCBD

* SSCBD $\theta 33$

○ SSCBD $933 \& 1500$

Fig. 1. 1:1 scale plot of measured and predicted values of water content in NT,

CP and MP tillage treatments

The behaviors of all the tillage systems in five methods of measured versus predicted water contents of sandy loam soil are illustrated in Figure 1. The SSCBDO33 and SSCBDO33\&1,500 methods have the nearest distance to the 1:1 line and their regression coefficient is higher than in the case of other methods. 


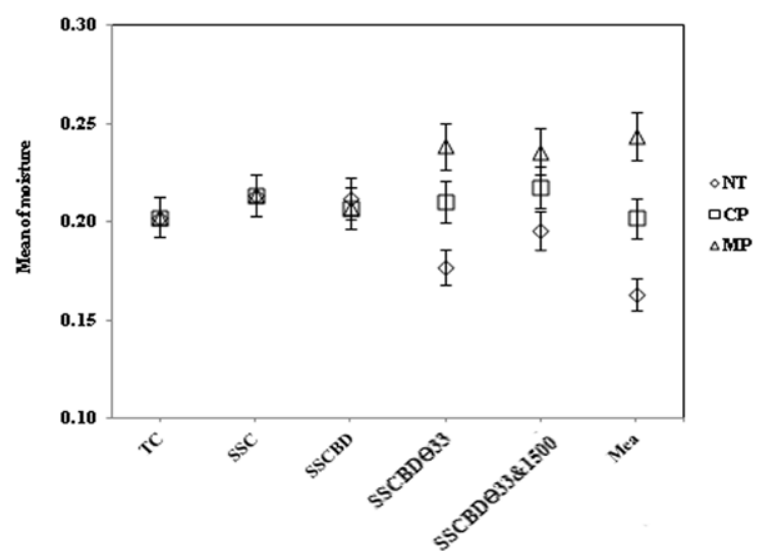

Fig. 2. Mean soil water contents for tillage levels. Error bars are $95 \%$ confidence intervals

Differences in store water were a result of significantly $(\mathrm{p}<0.05)$ greater water contents for MP compared with the NT in SSCBDO33 and SSCBDӨ33\&1,500 (Fig. 2). Some studies have reported that soil conditioners improved the soil physical characteristics under different conditions (Barzegar et al. 2002, Nyamangara et al. 2001).
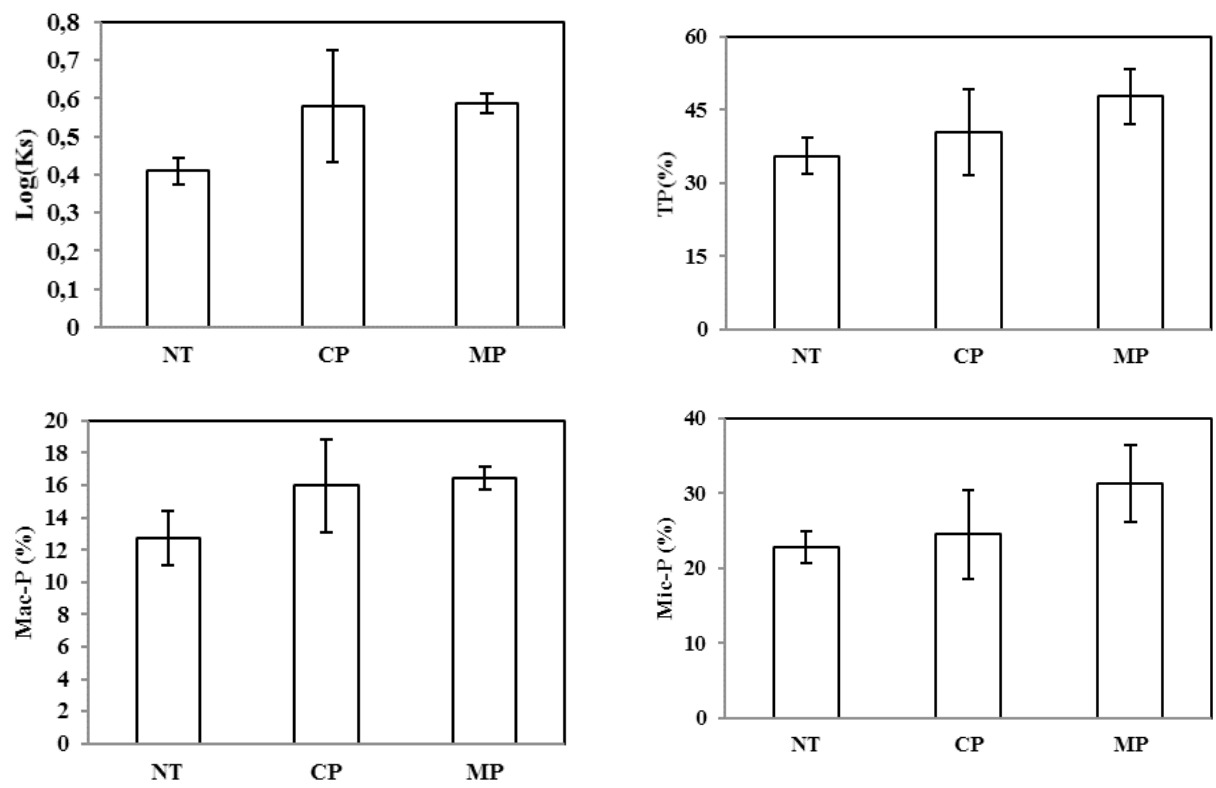

Fig. 3. Effect of tillage surfaces on physical soil properties

Tillage surfaces had an influence on soil porosity content and based on Figure 3, the NT treatment differed significantly from MP. It seems that in the MP tillage method, residual organic matter and manure were mixed with soil, and then the 
total porosity was increased. The $19 \%$ reduction in total porosity in the NT treatment was mainly due to decreases in macroporosity. Ferreras et al. (2000) in their three-year research reported that total soil porosity with diameters more than 20 micrometers in tillage treatments increased as compared to no-tillage system.

Tillage systems had a similar effect on microporous and total porosity (Fig. 3). The soil under this study had the unstable structure and the organic matter was too low in soil layer. Therefore, in no-tillage system, macropores, and micropores were decreased as compared to other tillage treatments. There were no significant differences in the soil properties between the NT and CP treatments (Fig. 3). Considering the soil layer of $0-22.5 \mathrm{~cm}$, no-tillage treatment was characterized by significantly lower hydraulic conductivity, total porosity, microporosity, and macroporosity as compared to the MP treatment. Results indicated that the tillage surfaces had an influence on Ks values and the range of changing in Ks was followed by NT $<\mathrm{CP}<\mathrm{MP}$ (Fig. 3). It seems that the tillage with the CP surface was not compacted which resulted in the rise of Ks values.

Bhattacharyya et al. (2005) found that Ks values in the no-tilled soil were significantly higher as compared to the tilled soil. Ciollaro and Lamaddalena (1998) reported that after tillage, Ks values were higher than in the case of tilled soil. Aikins and Afuakwa (2012) indicated that the highest soil penetration resistances were determined under no-tillage, and conversely, Miriti et al. (2013) reported that the various tillage practices did not significantly affect soil saturated hydraulic conductivity.

Table 4. Hydro-physical properties in the soil layers of 0-7.5, 7.5-15, 15-22.5 and $0-22.5 \mathrm{~cm}$ under different tillage practices

\begin{tabular}{ccccc}
\hline \multirow{2}{*}{ Soil properties } & Soil layer $(\mathrm{cm})$ & \multicolumn{3}{c}{ Treatments } \\
\cline { 2 - 5 } & $0-7.5$ & 1.45 & CP & MP \\
\hline \multirow{3}{*}{ Bulk density $\left(\mathrm{mg} \cdot \mathrm{m}^{-3}\right)$} & $7.5-15$ & 1.57 & 1.23 & 1.15 \\
& $15-22.5$ & 1.62 & 1.59 & 1.28 \\
& $0-22.5$ & $\mathbf{1 . 5 5}$ & $\mathbf{1 . 3 7}$ & 1.43 \\
& $0-7.5$ & 45.2 & 53.4 & $\mathbf{1 . 2 9}$ \\
\hline \multirow{2}{*}{ Porosity (\%) } & $7.5-15$ & 40.7 & 47.6 & 56.6 \\
& $15-22.5$ & 38.9 & 43.5 & 51.7 \\
& $0-22.5$ & $\mathbf{4 1 . 6 0}$ & $\mathbf{4 8 . 1 7}$ & $\mathbf{5 1 . 4 0}$ \\
\hline \multirow{3}{*}{ Macroporosity (\%) } & $0-7.5$ & 16.8 & 20.1 & 18.1 \\
& $7.5-15$ & 14.2 & 18.8 & 17.1 \\
& $15-22.5$ & 13.6 & 19.4 & 18.3 \\
& $0-22.5$ & $\mathbf{1 4 . 8 7}$ & $\mathbf{1 9 . 4 5}$ & $\mathbf{1 7 . 8 3}$ \\
\hline \multirow{2}{*}{ Microporosity $(\%)$} & $0-7.5$ & 28.4 & 33.3 & 38.5 \\
& $7.5-15$ & 26.4 & 28.8 & 34.8 \\
& $15-22.5$ & 25.3 & 24.1 & 27.5 \\
& $0-22.5$ & $\mathbf{2 6 . 6 9}$ & $\mathbf{2 8 . 7 2}$ & $\mathbf{3 3 . 6 0}$ \\
\hline
\end{tabular}




\begin{tabular}{ccccc}
\hline \multirow{2}{*}{ Soil properties } & \multirow{3}{3}{ Treatments } \\
& \multirow{2}{*}{ Soil layer $(\mathrm{cm})$} & NT & CP & MP \\
\cline { 2 - 5 } & $0-7.5$ & 0.015 & 0.020 & 0.022 \\
Total available water & $7.5-15$ & 0.013 & 0.015 & 0.020 \\
$\left(\mathrm{~m} \cdot \mathrm{m}^{-1}\right)$ & $15-22.5$ & 0.010 & 0.012 & 0.014 \\
& $0-22.5$ & $\mathbf{0 . 0 3 8}$ & $\mathbf{0 . 0 4 7}$ & $\mathbf{0 . 0 5 6}$ \\
\hline \multirow{2}{*}{$\mathrm{Ks}\left(\mathrm{cm} \cdot \mathrm{hr}^{-1}\right)$} & $0-7.5$ & 2.88 & 5.13 & 4.17 \\
& $7.5-15$ & 2.57 & 4.90 & 3.89 \\
& $15-22.5$ & 2.29 & 2.19 & 3.55 \\
& $0-22.5$ & $\mathbf{2 . 5 8}$ & $\mathbf{4 . 0 7}$ & $\mathbf{3 . 8 7}$ \\
\hline
\end{tabular}

The highest values in all examined parameters except for bulk density were obtained under all treatment practices for top soil layer of $0-7.5 \mathrm{~cm}$. As was expected, the no-till treatment had the highest bulk density and provided the lowest total porosity (Table 4). The greatest effects of bulk density reduction were observed under the MP treatment because of tillage and soil disturbance. Reduced tillage also showed increased bulk density in comparison with MP tillage and bulk density in all layers was higher in the no-tillage rather than in the other tillage systems $(0-22.5 \mathrm{~cm})$, the finding in similar studies confirmed these results in different tillage systems (Czyż and Dexter 2008, Ji et al. 2013, Afzalinia and Zabihi 2014).

Differences in macroporosity were found after applying tillage treatments in the 0-30 cm layer, where macroporosity was the lowest for NT treatments. Changes in the microporosity were observed in the first and second layers sampled after tillage system application with the highest value in MP and CP in the $0-7.5 \mathrm{~cm}$ layer. Higher TAW in $30 \mathrm{~cm}$ soil layer under the MP treatment could be explained by moldboard tillage treatment that increased the number of microspores that can help water retention (Table 4). Aikins and Afuakwa (2012) showed that the non-tilled soils had the lowest moisture contents.

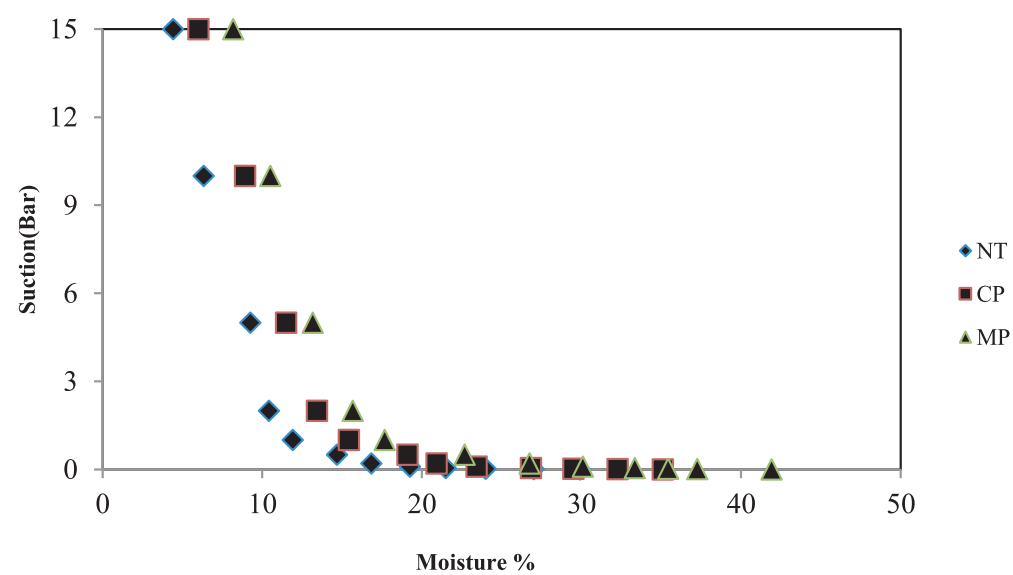

Fig. 4. Variation in soil water characteristic curve (SWCC) behavior due to different tillage systems 

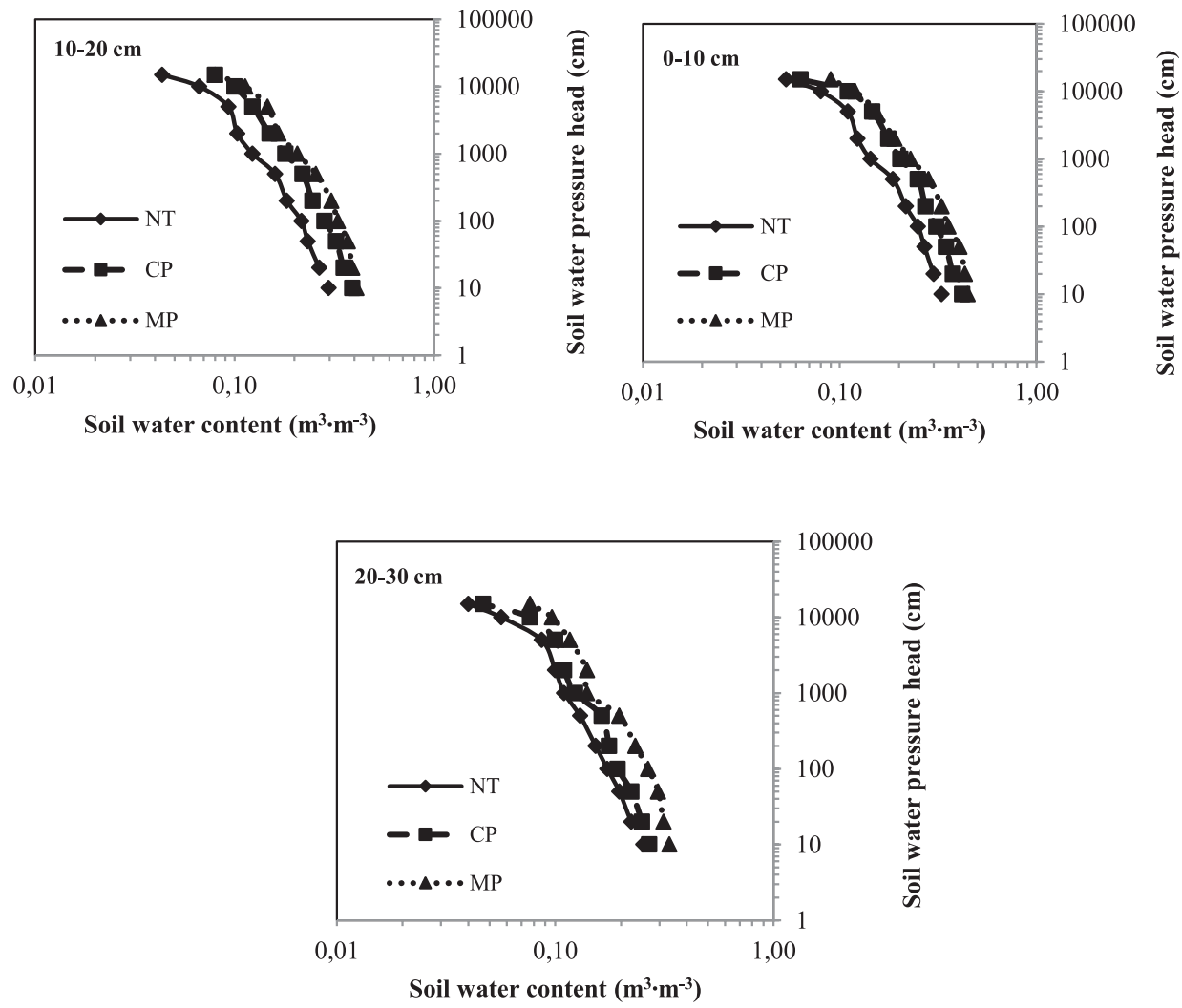

Fig. 5. Soil water characteristic curve data presented in linear at different depths

Tillage practices had an important effect on the soil water retention curve. Effect of tillage on SWCC for each depth can be evaluated from the information provided in Figure 5. SWCC for the MP tillage plot was above the SWCC for NT and CP. Figures 4 and 5 show that the tillage system had affected on the water retention and total available water capacity of the soil. Tillage increased the soil pore space; subsequently, the water retained by the soil was increased. In a similar study, Daraghmeh et al. (2008) reported that soil moisture at any pressure head was higher under reduced tillage rather than conventional one.

\section{CONCLUSIONS}

The short-term effects of three different tillage practices on soil physical properties, available water, soil water retention curve and hydraulic conductivity were evaluated.

Simulation by RETC indicated that bulk density did not change the accuracy of the methods, but with the adding of moisture points, the accuracy was 
increased. The S-index, which was also affected by tillage, was greater than 0.066 that indicated the good soil physical quality.

The results of this study indicated that soil compaction decreased when moldboard tillage (MP) is used as compared to the other tillage practices, the topsoil is loosened by offensive ploughing with moldboard tillage in such a way that it reduces bulk density as compared to no-tillage practice. According to the results, no-till topsoil layer has greater bulk density, lower saturated hydraulic conductivity and available water than the same layer with minimum and conventional tillage treatments. Also, tilled treatments increased total porosity, macroporosity, and microporosity. This experiment showed that soil physical properties were influenced by different tillage systems. Tillage systems generally affected the ability of soils as far as available water capacity is concerned.

\section{REFERENCES}

[1] Adefemi, B.A., Wole, A.C., 2013. Soil-Water Characteristics Curves for Compacted Abandoned Dumpsite Soil. Department of Civil Engineering, Osun State University, Vol. 18, Bund. Pp. 3315-3338.

[2] Afzalinia, S., Zabihi, J., 2014. Soil compaction variation during corn growing season under conservation tillage. Soil Tillage Research, 137: 1-6. DOI: 10.1016/j.still.2013.11.003.

[3] Aikins, S.H.M., Afuakwa, J.J., 2012. Effect of four different tillage practices on soil physical properties under cowpea. Agriculture and Biology Journal of North America, 3: 17-24. DOI:10.5251/abjna.2012.3.1.17.24.

[4] Alletto, L., Coquet, Y., 2009. Temporal and spatial variability of soil bulk density and near saturated hydraulic conductivity under two contrasted tillage management systems. Geoderma, 152: 85-94. DOI: 10.1016/j.geoderma.2009.05.023.

[5] American Society for Testing and Materials (ASTM) D5084-03, 2003. Standard Test Methods for Measurement of Hydraulic Conductivity of Saturated Porous Materials Using a Flexible Wall Permeameter. ASTM International, West Conshohocken, PA.

[6] Barzegar, A.R., Yousefi, A., Daryashenas, A., 2002. The effect of addition of different amounts and types of organic materials on soil physical properties and yield of wheat. Plant and Soil, 247(2): 295-301. DOI: 10.1023/A:1021561628045.

[7] Bhattacharyya, R., Prakash, V., Kundu, S., Gupta, H.S., 2005. Effect of tillage and crop rotations on pore size distribution and soil hydraulic conductivity in sandy clay loam soil of the Indian Himalayas. Soil Tillage Research, 86: 129-140. DOI: 10.1016/j.still.2005.02.018

[8] Ciollaro, G., Lamaddalena, N., 1998. Effect of tillage on the hydraulic properties of a vertic soil. Agricultural Engineering Research, 71: 147-155. DOI: 10.1006/jaer.1998.0312.

[9] Calonego, J.C., Rosolem, C.A., 2011. Soil water retention and s index after crop rotation and chiselling. Revista Brasileira de Ciencia do Solo, 35: 1927-1937.

DOI: $10.1590 / \mathrm{S} 0100-06832011000600009$.

[10] Czyż, E.A., Dexter, A.R., 2008. Soil physical properties under winter wheat grown with different tillage systems at selected locations. International Agrophysics, 22: 191-200.

[11] Daraghmeh, O.A., Jensen, J.R., Petersen, C.T., 2008. Near-saturated hydraulic properties in the surface layer of a sandy loam soil under conventional and reduced tillage. Soil Science Society of America Journal, 72: 1728-1737. DOI:10.2136/sssaj2007.0292.

[12] Dexter, A.R., 2004. Soil physical quality: Part I. Theory, effects of soil texture, density and organic matter, and effects on root growth. Geoderma, 120: 201-214.

DOI: 10.1016/j.geoderma.2003.09.004. 
[13] Dexter, A.R., Czyż, E.A., 2007. Applications of S-theory in the study of soil physical degradation and its consequences. Land Degradation \& Development, 18: 369-381.

DOI: $10.1002 / 1 \mathrm{dr} .779$.

[14] Dexter, A.R., Richard, G., 2009. Tillage of soils in relation to their bi-modal pore size distributions. Soil Tillage Research, 103: 113-118. DOI: 10.1016/j.still.2008.10.001.

[15] Ferreras, L.A., Costa, J.L., Garcia, F.O., Pecorari, C., 2000. Affects of no-tillage on some soil physical properties of a structural degraded Petrocalcic Paleudoll of the southern "Pampa" of Argentina. Soil and Tillage Research, 54: 31-39. DOI: 10.1016/S0167-1987(99)00102-6.

[16] Gate, O.P., Czyz, E.A., Dexter, A.R., 2006. Soil physical quality, S, as a basis for relationships between some key physical properties of arable soils. Advance in GeoEcology, 38: 102-109.

[17] Givi, J., Prasher, S.O., Patel, R.M., 2004. Evaluation of pedotransfer functions in predicting the soil water contents at field capacity and wilting point. Agricultural Water Management, 70: 83-96. DOI: 10.1016/j.agwat.2004.06.009.

[18] Gill, S.M., 2012. Temporal variability of soil hydraulic properties under different soil management practices. University of Guelph, Ontario, Canada ( $\mathrm{PhD}$ thesis).

[19] Jabro, J.D., Iversen, W.M., Stevens, W.B., Evans, R.G., Mikha, M.M., Allen, B.L., 2015. Effect of three tillage depths on sugarbeet response and soil penetrability resistance. Agronomy Journal, 107: 1481-1488. DOI:10.2134/agronj14.0561.

[20] Ji, B., Zhao, Y., Mu, X., Liu, K., Li, C., 2013. Effects of tillage on soil physical properties and root growth of maize in loam and clay in central China. Plant Soil Environment, 59: 295-302. DOI: 10.17221/57/2013-PSE.

[21] Kovac, K., Zak, S., 1999. The effect of different types of soil cultivation on its physical and hydrophysical properties. ROSTLIN VYR, 45(8): 359-364.

[22] Krause, P., Boyle, D.P., Bäse, F., 2005. Advances in Geosciences Comparison of different efficiency criteria for hydrological model assessment. Advances in Geosciences, 5: 89-97.

[23] Lin, B., Cerato, AB., 2012. Investigation on Soil-Water Characteristic Curves of Untreated and Stabilized Highly Clayey Expansive Soils. Geodetic Geology Engineering, 30: 803-812. DOI: 10.1007/s10706-012-9499-0.

[24] Miriti, J.M., Kironchi, G., Esilaba, A.O., Gachene, C.K., Heng, L.K., Mwang, D.M., 2013. The effect of tillage systems on soil physical properties and water conservation in a sandy loam soil in Eastern Kenya. Journal of Soil Sciences and Environmental Management, 4: 146-154. DOI: $10.5897 /$ jssem2013.395.

[25] Mualem, Y., 1976. A new model for predicting the hydraulic conductivity of unsaturated porous media. Water Resources Research, 12: 513-522. DOI: 10.1029/WR012i003p00513.

[26] Nkakini, S.O., Fubara-Manuel, I., 2012. The effects of tillage methods on soil penetration resistance, porosity and okra yield. Research Journal of Applied Sciences, Engineering and Technology, 4: 387-392.

[27] Nyamangara, J., Gotosa, J., Mpofu, SE., 2001. Cattle manure effects on structural stability and water retention capacity of a granitic sandy soil in Zimbabwe. Soil and Tillage Research, 62: 157-162. DOI: 10.1016/S0167-1987(01)00215-X.

[28] Schaap, M.G., Leij, F.J., Van Genuchten, M Th., 2001. ROSEETA: A computer program for estimating soil hydraulic parameters with hierarchical pedotransfer functions. Journal of Hydrology, 251: 163-176. DOI: 10.1016/S0022-1694(01)00466-8.

[29] Schwen, A., Bodner, G., Loiskandl, W., 2011. Time-variable soil hydraulic properties in near-surface soil water simulations for different tillage methods. Agricultural Water Management, 99: 42-50. DOI:10.1016/j.ag wat.2011.07.020.

[30] Tormena, C.A., Pda Silva, A., Imhoff, S.D.C., 2008. Quantification of the soil physical quality of a tropical oxisol using the S index. Scientia Agricola, 65: 56-60.

DOI: 10.1590/S0103-90162008000100008.

[31] Tyler, S.W., Wheatcraft, S.W., 1992. Fractal scaling of soil particle-size distributions: Analysis and Limitations. Soil Science Society of America Journal, 56: 362-369. 
[32] Van Genuchten, M.Th., 1980. A closed form equation for predicting the hydraulic conductivity of unsaturated soils. Soil Science Society of America Journal, 44: 892-898. DOI:10.2136/ sssaj1992.03615995005600020005x.

[33] Van Genuchten, M.Th., Leij, FJ., Yates, SR., 1991. The RETC code for quantifying the hydraulic functions of unsaturated soils. US-EPA, Ada, Oklahoma. Report. 600: 2-91/ 065.

[34] Walczak, R.T., Moreno, F., Slawin S.C., 2006. Modeling of soil water retention curve using soil solid phase parameters. Journal of Hydrology, 329: 527-533. DOI: 10.1016/j.jhydrol.2006.03.005. 